\title{
ANALISIS PERHITUNGAN HARGA POKOK PRODUKSI DALAM MENETAPKAN HARGA JUAL PADA HOLLAND BAKERY BOULEVARD MANADO
}

\author{
Cindy Shelly Lumowa ${ }^{1}$, Jantje J. Tinangon ${ }^{2}$, Anneke Wangkar ${ }^{3}$ \\ ${ }^{1,2,3}$ Fakultas Ekonomi dan Bisnis, Jurusan Akuntansi, Universitas Sam Ratulangi, Jl. Kampus UNSRAT \\ Manado, Indonesia, 95115 \\ E-mail: cindyshelly15@gmail.com
}

\begin{abstract}
Calculation of the cost of production is something that needs to be considered in determining the selling price of the product.Calculation of the cost of production that is right and accurate is something that needs to be done by every company, without a precise and accurate calculation of the cost of production, the manufacturing company concerned will experience in setting the selling price of a product. The purpose of this study was to determine the cost classification applied by Holland Bakery Boulevard Manado in calculating the cost of production, to find out the calculation of the cost of production of Holland Bakery Boulevard Manado in setting selling price and find out the determination of product selling price applied by Holland Bakery Boulevard Manado. Data analysis method used for this research is descriptive analysis method. The collection of cost of goods manufactured is the process cost method, while the method of determining the cost of production uses the full costing approach. There is a difference in the selling price per packet of bread between Holland Bakery Boulevard Manado with a theory caused by differences in the allocation of costs and determination of mark up between companies and theories.The company's selling price is lower than the theory that the difference for chocolate bread is $R p$. 1.589, then for cheese bread Rp. 1.910, and for srikaya bread Rp. 2.449.
\end{abstract}

Keywords: cost of goods manufactured; process cost method; full costing

\section{PENDAHULUAN}

Perkembangan dunia ekonomi di Indonesia saat ini cukup baik setiap tahun. Hal ini dapat dilihat dari makin banyak perusahaan-perusahaan yang telah berdiri beberapa tahun terakhir ini, memicu perusahaan untuk bekerja lebih keras dalam berlomba menghasilkan laba yang merupakan salah satu tujuan perusahaan (Kiay et al., 2013; Pontoh dan Budiarso, 2018). Persaingan yang ketat saat ini memaksa para pengusaha untuk memilih cara agar dapat mempertahankan kelangsungan usahanya, maka perusahaan dituntut untuk lebih inovatif dan mempunyai strategi yang tepat dan jeli agar mampu bersaing. Sebagian besar perusahaan pada dasarnya bertujuan untuk menghasilkan keuntungan yang maksimal. Memperoleh laba yang maksimal, khususnya perusahaan yang bergerak di bidang manufaktur, peranan perhitungan harga pokok produksi dan perhitungan harga jual sangat dibutuhkan, hal ini berkaitan dengan persaingan perusahaan dalam menetapkan harga jual produk dengan pesaing perusahaan manufaktur lain yang bergerak pada bidang sejenis.

Perusahaan-perusahaan di Kota Manado yang saat ini semakin berkembang dalam bidang ekonomi. Dari tahun ke tahun perusahaan-perusahaan di Kota Manado mulai menunjukkan persaingan yang ketat dalam membangun usaha, setiap tahun semakin banyak toko roti yang dibuka di Kota Manado, tetapi karena persaingan yang ketat banyak toko roti yang tidak bisa mempertahankan usahanya karena karena tidak mampu mengatur biaya sehingga tidak menghasilkan keuntungan. Akuntansi biaya pada perhitungan harga pokok produksi berfungsi menetapkan, menganalisa, dan mengungkapkan pos-pos biaya mendukung laporan keuangan agar dapat menunjukkan data yang alami. Akuntansi biaya 
mempersiapkan data-data biaya untuk berbagai tujuan hingga biaya-biaya yang terjadi pada perusahaan harus dikelompokkan dan dicatat dengan semestinya, sehingga memperoleh perhitungan harga pokok produksi. Perhitungan harga pokok produksi adalah keadaan yang perlu dilihat dalam menetapkan harga jual dari produk. Perhitungan harga pokok produksi yang tepat dan benar merupakan sesuatu yang harus dilakukan perusahaan karena tanpa adanya perhitungan harga pokok produksi yang tepat dan benar maka perusahaan manufaktur yang berhubungan akan mengalami masalah saat menetapkan harga jual suatu produk.

Proses produksi perusahaan Holland Bakery Boulevard Manado perlu diingat untuk menata biaya-biaya yang dikeluarkan perusahaan berguna dan efektif. Holland Bakery Boulevard Manado adalah perusahaan manufaktur yang beroperasi dalam industri roti, oleh sebab itu dalam menghitung pokok produksi dari produk yang didapatkan perlu untuk diingat serta serta ditelah lebih lanjut untuk mengurangi biaya-biaya yang tidak dibutuhkan bagi perusahaan. Saat ini terdapat beberapa produk yang dibuat oleh perusahaan tersebut, maka dibutuhkan ketelitian saat menghitung harga pokok produksi setiap produk.

\section{TINJAUAN PUSTAKA}

Menurut Suwardjono (2015:10), akuntansi dideskripsikan sebagai seperangkat alat yang mempelajari implementasi penyedia jasa berupa laporan keuangan kuantitatif bagian organisasi dalam suatu lingkup negara tertentu dengan cara penyajian (pelaporan) informasi tersebut kepada kelompok yang berkepentingan untuk dijadikan alasan dalam pengambilan hasil ekonomi. Menurut Sujarweni (2015:1), akuntansi manajemen merupakan salah satu bagian ilmu akuntansi yang mengkaji cara untuk mendapatkan laporan keuangan untuk pihak manajemen yang akan digunakan untuk mengambil keputusan. Menurut Samryn (2015:4), akuntansi manajemen adalah bidang akuntansi yang berpacu pada penyediaan, yang didalamnya termasuk pengembangan dan penafsiran informasi akuntansi bagi para manajer nantinya akan digunakan sebagai bahan perencanaan, pengendalian operasi dalam mengambil keputusan. Menurut Ahmad (2013:4), akuntansi manajemen adalah penerapan metodemetode dan konsep yang benar dalam mengolahan data ekonomi yang di proyeksi dari suatu satuan usaha dalam membantu manajemen dan penyusunan rencana untuk tujuan-tujuan ekonomi yang rasional dalam pembuatan keputusan-keputusan rasional dengan suatu pandangan ke arah pencapaian tujuan tersebut.

Menurut Mulyadi (2016:18), akuntansi biaya merupakan proses penulisan, penggolongan, perumusan, penyajian biaya, pembuatan dan pemasaran produk, dengan sistem-sistem tertentu, serta pengertian terhadapnya. Menurut Widyastuti (2017:40), akuntansi biaya mengidentifikasi, menjelaskan, mengukur, membuat pelaporan dan menganalisis berbagai unsur direct cost dan indirect cost yang berkaitan dengan pembuatan serta pemasaran barang atau jasa, juga mengukur kinerja, kualitas produk, dan produksivitas. Menurut Dunia dan Wasilah (2011:4), akuntansi biaya merupakan bagian dari akuntansi manajemen dimana adalah suatu bidang khusus akuntansi yang menekankan pada penentuan dan pengendalian biaya. Menurut Sugawa, et.al. (2018), akuntansi biaya adalah suatu proses pencatatan, pengklasifikasian, perhitungan, dan penyajian biaya-biaya pembuatan dan penjualan produk barang maupun jasa dengan cara tertentu sebagai alat pembantu bagi manajemen dalam pengambilan keputusan.

Menurut Kautsar (2013:62), akuntansi biaya menduduki peranan yang penting terhadap pihak manajemen saat merencanakan dan memperhatikan kegiatan, meningkatkan kualitas produk dan efisiensi, serta pada pengambilan keputusan baik strategi maupun kepastian rutin. Biaya merupakan jumlah uang yang dinyatakan dari asal (ekonomi) yang dikorbankan (terjadi dan akan terjadi) untuk menemukan suatu atau mencapai tujuan tertentu (Harnanto, 2017:22). Menurut Supriyono (2011:217), ada beberapa penggolongan biaya, yaitu: penggolongan biaya berdasarkan fungsi pokok dari aktivitas perusahaan, penggolongan 
biaya sesuai dengan periode akuntansi dimana biaya akan dibebankan, penggolongan biaya sesuai dengan tendensi perubahannya terhadap aktivitas atau kegiatan atau volume, dan penggolongan biaya sesuai dengan objek atau pusat biaya yang dibiayai.

Menurut Sodikin (2015:22), biaya produksi merupakan biaya untuk mencapai atau membuat barang atau produk. Biaya ini dipertemukan dengan penghasilan pada waktu penjualan produk. Dunia dan Wasilah (2011:143), pengertian harga pokok produksi (manufacturing cost) adalah biaya-biaya yang secara langsung memiliki hubungan dengan produksi yaitu biaya bahan langsung dan tenaga kerja langsung. Menurut Hansen dan Mowen (2013:361), harga pokok produksi menggambarkan total biaya barang yang disediakan yang merupakan biaya manufaktur dari bahan langsung, tenaga kerja langsung, dan overhead. Tujuan harga pokok produksi menurut Mulyadi (2012:7) adalah sebagai berikut: (a) biaya produksi merupakan salah satu data yang dipertimbangkan selain data non produksi dalam penentuan harga jual produk yang dipasarkan; (b) untuk memantau realisasi biaya produksi; (c) menghitung laba rugi bruto perusahaan pada periode tertentu; dan (d) menentukan harga pokok produk dalam proses dan produk selesai yang disajikan dalam bentuk neraca.

Pengerjaan dalam produk terdapat dua kelompok biaya, yaitu: biaya produksi dan biaya non produksi. Biaya produksi adalah biaya-biaya dialirkan pada pembuatan bahan baku menjadi produk, sebaliknya biaya non produksi adalah biaya-biaya yang dialirkan pada aktivitas non produksi, sebagai kegiatan pemasaran dan kegiatan administrasi dan umum. Menurut Mulyadi (2016:17), metode penetapan biaya produksi ialah metode memperhitungkan bagian-bagian biaya ke dalam biaya produksi. Dalam memperhitungkan bagian-bagian biaya pada biaya produksi, terdapat 2 (dua) pendekatan yaitu: pendekatan full costing dan variable costing. Menurut Mulyadi (2015:125), full costing merupakan metode penetapan harga pokok produksi yang memperhitungkan seluruh bagian biaya produksi ke dalam harga pokok produksi, yang terdiri dari biaya bahan baku, biaya tenaga kerja serta biaya overhead pabrik, baik berkarakter variable maupun tetap.

Menurut Mulyadi (2015:125), variable costing ialah metode penetapan harga pokok produksi yang sekedar memperhitungkan biaya produksi yang berkarakter variabel pada harga pokok produksi yang terdiri biaya produksi seperti biaya bahan baku, biaya tenaga kerja, serta biaya overhead pabrik variable.Menurut Mulyadi (2015:125), harga jual ialah banyaknya harga yang ditanggungkan pada konsumen yang diperoleh atau dihitung dari biaya produksi ditambah biaya non produksi dan keuntungan yang diinginkan. Harga jual sama seperti biaya produksi ditambah keuntungan. Penetapan harga jual merupakan ketentuan manajemen mengenai apa yang perlu ditanggungkan pada produk dan jasa. Ini adalah keputusan terbaik yang dapat merubah kualitas yang akan diproduksi dan menjual barang sebesar penghasilan operasi perusahaan perlu membuat dan menjual produk sebanyak keuntungan dari setiap produk tambahan yang melebihi biaya produksi.

Litdia (2016:61-68), mengemukakan penetapan harga produksi yang dilakukan PT. Veneer Products Indonesia sudah baik sehingga perusahaan dapat langsung menentukan harga jual yang diinginkan perusahaan. Menurut Ramdani (2018), Usaha Mikro Kecil Menengah Gunung Jaya Makassar dalam menentukan harga pokok menggunakan pendekatan full costing sebab dalam menghitung semua unsur biaya produksi ke dalam harga pokok produksi. Pelealu et al. (2018) mengemukakan bahwa terdapat perbedaan dari perhitungan harga pokok produksi menurut metode perusahaan dengan full costing, hal ini terjadi dikarenakan ada perbedaaan pembebanan sejak awal. Slat (2013), menemukan bahwa dalam penetapan harga jual ada beberapa faktor yang perlu dipertimbangkan yaitu biaya dan laba, selebihnya penting untuk mengetahui persentase keuntungan yang diinginkan sehingga dalam penetapan keuntungan tidak telalu tinggi. 


\section{METODE PENELITIAN}

Jenis penelitian yang digunakan yaitu penelitian metode deskriptif kualitatif karena penelitian ini memakai fakta atau kejadian serta keadaan yang sedang terjadi pada perusahaan untuk memperoleh kesimpulan dari penelitian dan saran yang dapat digunakan bagi perusahaan. Penelitian ini membandingkan harga jual yang ditetapkan perusahaan dengan metode full costing melalui laporan biaya produksi Holland Bakery Boulevard Manado. Penelitian ini dilakukan di Holland Bakery Boulevard Manado yang terletak di Boulevard Manado Jl. Piere Tendean No.89, Sario Utara, Kota Manado, Sulawesi Utara. Data kualitatif dalam peneliatian ini mengenai gambaran umum sejarah Holland Bakery. Data kualitatif adalah data yang disiapkan dalam bentuk sejarah dan uraian struktur organisasi dari Holland Bakery Boulevard Manado. Data kuantitatif pada penelitian ini berupa laporan biaya produksi dan harga jual dari perusahaan. Data kuantitatif adalah tata cara penelitian yang menghasilkan bentuk angka-angka.

Sumber data yang digunakan pada penelitian ini adalah data primer dan data sekunder. Data primer pada penelitian ini adalah hasil wawancara langsung dengan operasional manager di Holland Bakery Manado. Data sekunder yaitu menggunakan studi pustaka yang dilakukan pada buku yang diperoleh berdasarkan catatan-catatan yang berhubungan dengan penelitian. Penelitian ini menggunakan metode pengumpulan data dalam bentuk: wawancara, dan dokumentasi. Penelitian ini menggunakan metode analisis deskriptif dengan teknik analisis pendekatan full costing dalam menghitung biaya produksi dan menentukan harga jual, yaitu menguraikan perhitungan harga pokok produksi dalam menetapkan harga jual pada Holland Bakery Boulevard Manado.

1. Pengumpulan data berupa kegiatan wawancara dengan pihak Holland Bakery mengenai proses produksi. Selain itu, penelitian ini menggunakan data berupa dokumentasi biaya produksi pada Holland Bakery Boulevard Manado.

2. Melakukan analisis perhitungan yang digunakan oleh perusahaan dan membandingkan dengan metode full costing.

3. Mengambil kesimpulan serta memberikan saran pada pihak Holland Bakery.

\section{HASIL PENELITIAN DAN PEMBAHASAN}

\subsection{Hasil penelitian}

Hasil penelitian yang dilakukan pada Holland Bakery Boulevard Manado mengenai perhitungan harga pokok produksi ditemukan bahwa dalam penetapan harga jual ada kekurangan dalam menghitung harga pokok produksi. Biaya overhead pabrik variable terdapat biaya bahan bakar yang tidak seharusya dibebankan pada biaya overhead pabrik variable. Perusahaan masih menggunakan harga pokok proses dalam menghitung harga pokok produksi, sehingga dalam menghitung harga jual biaya yang dimasukkan kurang maksimal. Tabel 1 menyajikan perhitungan harga pokok produksi menurut perusahaan.

Tabel 1. Perhitungan harga pokok produksi

\begin{tabular}{|c|c|c|c|}
\hline & Roti cokelat & Roti keju & Roti srikava \\
\hline Biaya bahan baku & Rp. 82.937 .400 & Rp. 72.910 .500 & Rp. 38.350 .000 \\
\hline Biaya tenaga kerja langsung & Rp. 13.000 .000 & 13.000 .000 & 13.000 .000 \\
\hline Biaya overhead pabrik variable & Rp. 72.640 .000 & 72.640 .000 & Rp. 72.640 .000 \\
\hline Biaya overhead pabrik tetap & Rp. $\quad 7.462 .000$ & 7.462 .000 & 7.462 .000 \\
\hline Total biaya produksi & Rp. 176.039.400 & Rp. 166.012.500 & Rp. 131.452.000 \\
\hline
\end{tabular}

Laba yang ditetapkan dalam menghitung harga jual menurut perusahaan adalah sebesar 35\% sehingga harga jual menurut perusahaan Roti Cokelat adalah Rp. 8.463/bungkus, Roti Keju adalah Rp. 9.578/bungkus, dan untuk Roti Srikaya adalah Rp. 9.480/bungkus. 


\section{Roti cokelat:}

Harga pokok per bungkus $=\frac{\text { Rp. } 176.039 .400}{28.080 \text { bungkus }}=$ Rp. 6.269/bungkus

Harga jual per bks $\quad=$ Biaya produksi per bks + Persentase Mark up

$$
\begin{array}{lll}
= & \text { Rp. } 6.269 & + \\
= & \text { Rp. } 6.269 & \text { Rp. } 6.269 \times 35 \%) \\
= & \text { Rp. 8.463/bungkus } &
\end{array}
$$

Roti keju:

\begin{tabular}{|c|c|c|c|c|}
\hline Harga pokok per bungkus & $=$ & $\begin{array}{c}\text { Rp. } 131.452 .000 \\
18.720 \text { bungkus }\end{array}$ & $=$ & Rp. 7.022/bungkus \\
\hline Harga jual per bks & $\begin{array}{l}= \\
= \\
=\end{array}$ & $\begin{array}{c}\text { Biaya produksi per bks } \\
\text { Rp. } 7.022 \\
\text { Rp. } 7.022 \\
\text { Rp. } 9.480 / \text { bungkus }\end{array}$ & $\begin{array}{l}+ \\
+ \\
+\end{array}$ & $\begin{array}{l}\text { Persentase Mark up } \\
\text { (Rp. } 7.022 \times 35 \%) \\
\text { Rp. } 2.458\end{array}$ \\
\hline
\end{tabular}

$\begin{aligned} \text { Harga pokok per bungkus } & =\frac{\text { Rp. 166.012.500 }}{23.400 \text { bungkus }}=\text { Rp. 7.095/bungkus } \\ \text { Harga jual per bks } & =\text { Biaya produksi per bks }+ \text { Persentase Mark up } \\ & =\text { Rp. 7.095 } \\ & =\text { Rp. 7.095 } \\ & =\text { Rp. 9.578/bungkus }\end{aligned}$

\section{Roti srikaya:}

Tabel 2 menunjukkan total harga jual per bungkus menurut perusahaan untuk Roti Cokelat adalah sebesar Rp. 237.641.040, Roti Keju adalah sebesar Rp. 224.125.200, dan Roti Srikaya adalah sebesar Rp. 117.465.600.

Tabel 2. Harga jual per bungkus menurut perusahaan

\begin{tabular}{llccc}
\hline No & Jenis Roti & $\begin{array}{c}\text { Total Produksi } \\
\text { Per Bulan }\end{array}$ & $\begin{array}{c}\text { Harga Jual Per } \\
\text { Bungkus }\end{array}$ & Jumlah \\
\hline 1 & Roti cokelat & 28.080 & Rp. 8.463 & Rp. 237.641.040 \\
2 & Roti keju & 23.400 & Rp. 9.578 & Rp. 224.125.200 \\
3 & Roti srikaya & 18.720 & Rp. 9.480 & Rp. 177.465.600 \\
\hline
\end{tabular}

Sumber : Data olahan, 2019

\subsection{Pembahasan}

Penetapan harga jual dengan menggunakan metode full costing terlebih dahulu harus dicari mark up yang didapat dengan rumus:

$$
\text { Mark up }=\frac{\text { Biaya non produksi }+ \text { Laba yang diharapkan }}{\text { Biaya Produksi }}
$$

Laba yang diharapkan oleh Holland Bakery dari penjualan roti tersebut sebesar $35 \%$ dari jumlah yang telah terjadi. Tabel 3 menunjukkan harga pokok produksi setelah dihitung ulang yang menjadi dasar penentuan harga jual untuk setiap jenis produk. 
Tabel 3. Perhitungan harga pokok produksi

\begin{tabular}{|c|c|c|c|}
\hline & Roti cokelat & Roti keju & Roti srikaya \\
\hline Biaya bahan baku & Rp. 82.937 .400 & Rp. 72.910 .500 & Rp. 38.350 .000 \\
\hline Biaya tenaga kerja langsung & Rp. 13.000 .000 & Rp. 13.000 .000 & Rp. 13.000 .000 \\
\hline Biaya overhead pabrik variable & Rp. 66.640 .000 & Rp. $\quad 66.640 .000$ & Rp. 66.640 .000 \\
\hline Biaya overhead pabrik tetap & Rp. $\quad 7.462 .000$ & Rp. $\quad 7.462 .000$ & Rp. $\quad 7.462 .000$ \\
\hline Total biaya produksi & Rp. 170.039.400 & Rp. 160.012.500 & Rp. 125.452.000 \\
\hline
\end{tabular}

\section{Roti cokelat}

Laba

$$
\begin{aligned}
& =\text { Rp. } 170.039 .400 \times 35 \% \\
& =\text { Rp. } 59.513 .790 \\
& =\frac{\text { Rp. } 53.620 .000+\text { Rp. } 59.513 .790}{\text { Rp. } 170.039 .400} \times 100 \% \\
& =\quad 66 \%
\end{aligned}
$$

Mark up

Total biaya produksi

Mark up 66\% x Rp. 170.039 .000

Total harga jual

$$
\begin{aligned}
& = \\
& =\frac{\text { Rp. 170.039.400 }}{\text { Rp. 112.226.004 }} \\
& =\frac{\text { Rp. 282.265.404 }}{\text { Rp. 282.265.404 }} \\
& =\text { Rp. 10.050 bungkus }
\end{aligned}
$$

Harga jual per bks

\section{Roti keju}

Laba

$=$ Rp. $160.012 .500 \times 35 \%$

$=$ Rp. 56.004.375

Mark up

$=\frac{\text { Rp. 53.620.000+Rp. 56.004.375 }}{\text { Rp. } 160.012 .500} \times 100 \%$

$=68 \%$

Total biaya produksi

Mark up 66\% x Rp. 160.012 .500

Total harga jual

$$
\begin{aligned}
& =\quad \text { Rp. } 160.012 .500 \\
& =\frac{\text { Rp. } 108.808 .500}{\text { Rp. } 268.821 .000}
\end{aligned}
$$

Harga jual per bks

Laba

Mark up

Total biaya produksi

Mark up 78\% x 125.452 .000

Total harga jual

$$
\begin{aligned}
& =\quad \text { Rp. 125.452.000 } \\
& =\quad \text { Rp. } 97.852 .560 \\
& =\quad \text { Rp. } 223.304 .560 \\
& =\frac{\text { Rp. } 223.304 .560}{18.720 \text { bungkus }}
\end{aligned}
$$

$=$ Rp. 11.929/bungkus 
Tabel 4 menunjukkan bahwa terdapat selisih harga jual per bungkus roti antara Holland Bakery Boulevard Manado dengan teori yang disebabkan karena perbedaan pengalokasian biaya dan penentuan mark up antara perusahaan dengan teori. Harga jual perusahaan lebih rendah dibandingkan dengan metode full costing yaitu selisih untuk Roti Cokelat adalah sebesar Rp. 1.589, kemudian untuk Roti Keju adalah sebesar Rp. 1.910, dan untuk Roti Srikaya adalah sebesar Rp. 2.449.

Tabel 4. Perbandingan harga jual per bungkus

\begin{tabular}{clccc}
\hline No. & Jenis Produk & $\begin{array}{c}\text { Harga jual per } \\
\text { bks menurut } \\
\text { perusahaan }\end{array}$ & $\begin{array}{c}\text { Harga jual per bks } \\
\text { menurut metode } \\
\text { full costing }\end{array}$ & Selisih \\
\hline 1. & Roti Cokelat & Rp. 8.463 & Rp. 10.052 & Rp. 1.589 \\
2. & Roti Keju & Rp. 9.578 & Rp. 11.488 & Rp. 1.910 \\
3. & Roti Srikaya & Rp. 9.480 & Rp. 11.929 & Rp. 2.449 \\
\hline
\end{tabular}

Sumber :Data olahan, 2019

\section{KESIMPULAN DAN SARAN}

\subsection{Kesimpulan}

Berdasarkan analisis mengenai harga pokok produksi dalam menetapkan harga jual pada Holland Bakery Boulevard Manado, maka dapat disimpulkan sebagai berikut:

1. Perhitungan harga pokok produksi yang dipakai oleh perusahaan menggunakan harga pokok berdasarkan proses pembuatan, sehingga terjadi kesalahan dalam menempatkan biaya produksi. Perusahaan menghitung biaya overhead pabrik variable disertai biaya bahan bakar kendaraan yang seharusnya biaya bahan bakar kendaraan dimasukkan kedalam biaya non produksi, sehingga dalam penetapan harga jual tidak maksimal karena perusahaan hanya menetapkan persentase mark up sebsar 35\%, padahal mark up harusnya dihitung dengan menggunakan total biaya produksi ditambah biaya laba yang diharapkan.

2. Perusahaan belum maksimal menghitung biaya produksi, masih ada biaya yang seharusnya masukkan kedalam biaya lain.

3. Perbedaan dari perhitungan harga jual perusahaan menggunakan metode full costing, perusahaan dapat menghitung biaya produksi secara menyeluruh sehingga dapat memudahkan perusahaan dalam menetapkan harga jual produk yang tepat.

\subsection{Saran}

Berdasarkan hasil penelitian, saran yang dapat diberikan pada Holland Bakery Boulevard Manado adalah sebagai berikut:

1. Metode full costing dapat dipertimbangkan oleh perusahaan dalam menentukan harga jual yang dihasilkan perusahaan, sehingga dapat mempermudah dalam menghitung laba yang akan diperoleh perusahaan.

2. Perbedaan harga jual yang terjadi dalam menghitung harga pokok produksi perusahaan dengan metode full costing harus diperhatikan sehingga dapat menjadi perbandingan jika perusahaan ingin menerapkan metode tersebut.

3. Penelitian selanjutnya disarankan untuk menghitung biaya produksi secara keseluruhan agar penetapan harga jual setiap produk dapat dilakukan secara tepat.

\section{DAFTAR PUSTAKA}

Ahmad, K. (2013). Akuntansi manajemen, Edisi Revisi Cetakan Kedelapan. Jakarta: Rajawali Pers.

Dunia, F. A., \& Wasilah. (2011). Akuntansi biaya, Edisi 2. Jakarta: Salemba Empat

Hansen, D. R., \& Mowen, M. M. (2013). Akuntansi manajerial, Edisi Kedelapan. Jakarta: Salemba Empat 
Harnanto, A. (2017). Akuntansi biaya: Konsep dan metodologi penggologan biaya elemen biaya produksi perhitungan harga pokok produksi, Cetakan Pertama. Yogyakarta: Andi Offset.

Kautsar, R. S. (2013). Akuntansi biaya: Pendekatan product costing, Cetakan Pertama. Jakarta: Akademia

Kiay, D. S., Morasa. J., \& Pontoh. W. Analisis perhitungan harga pokok produksi menggunakan metode variable costing pada PT. Celebes Minapratama Bitung. Jurnal Riset Akuntansi Going Concern, 8(4), 139-149. http://doi.org/10.32400/gc.8.4.25132.2013.

Litdia, L. (2016). Analisis penetapan harga pokok produksi sebagai dasar penentuan harga jual pada PT. Veneer Products Indonesia. Journal of Applied Business and Economics, 3(2), 61-68. http://dx.doi.org/10.30998/jabe.v3i2.1758.

Mulyadi. (2012). Akuntansi biaya, Edisi Kelima. Yogyakarta: Unit Penerbitan dan Percetakan Sekolah Tinggi Ilmu Manajemen Yayasan Keluarga Pahlawan Negara.

Mulyadi. (2015). Akuntansi biaya, Edisi 5. Yogyakarta: Unit Penerbitan dan Percetakan Sekolah Tinggi Ilmu Manajemen Yayasan Keluarga Pahlawan Negara.

Mulyadi. (2016). Sistem akuntansi, Edisi Ketiga. Yogyakarta: Salemba Empat.

Pelealu, A. J. H., Manoppo, W. S., \& Mangindaan, J. V. (2018). Analisis harga pokok produksi dengan menggunakan metode full costing sebagai dasar perhitungan harga jual (Studi kasus pada Kertina's Home Industry). Jurnal Administrasi Bisnis, 6(2), 3440. https://ejournal.unsrat.ac.id/index.php/jab/article/view/19850

Pontoh, W, \& Budiarso, N. S. (2018). Ipteks penerapan metode harga jual normal dalam penentuan harga jual jasa (Studi kasus pada usaha photocopy Gloria Manado). Jurnal Ipteks Akuntansi Bagi Masyarakat, 2(1), 21-30. https://doi.org/10.32400/jiam.2.1.2018.23523

Ramdani, M. R. (2018). Penetapan harga jual produk dengan pendekatan full costing dan variable costing pada UMKM Gunung Jaya Makassar. Jurnal Bisnis dan Kewirausahaan, 7(3), 235-345.https://osf.io/ubnwh/

Samryn, L. M. (2015). Akuntansi manajemen. Jakarta: Prenada Media.

Slat, A. H. (2013). Analisis harga pokok produk dengan metode full costing dan penentuan harga jual. Jurnal Riset Emba: Ekonomi Manajemen Bisnis dan Akuntansi, 1(3), 110117. https://ejournal.unsrat.ac.id/index.php/emba/article/view/1638

Sodikin, S. S. (2015). Akuntansi managemen: Sebuah pengantar, Edisi Kelima. Yogyakarta: Sekolah Tinggi Ilmu Manajemen Yayasan Keluarga Pahlawan Negara.

Sugawa, S. I., Ilat, V. \& Kalalo, K. (2018). Analisis perbandingan harga pokok produksi dengan metode full costing dan metode activity based costing dalam menetapkan harga jual ruko pada PT. Megasurya Nusalestari. Journal Riset Akuntansi Going Concern, 13(04), 165. https://doi.org/10.32400/gc.13.04.20947.2018

Sujarweni, V. W. (2015). Akuntansi biaya: Teori dan penerapannya. Yogyakarta: Pustaka Baru Press.

Supriyono, R. A. (2010). Akuntansi biaya: Pengumpulan biaya dan penentuan harga pokok, Buku Pertama Edisi Kedua. Yogyakarta: Badan Penerbitan Fakultas Ekonomi

Suwardjono. (2014). Teori akuntansi perekayasaan pelaporan keuangan, Edisi Ketiga. Yogyakarta: Badan Penerbitan Fakultas Ekonomi.

Widyastuti, T. (2017). Akuntansi biaya pendekatan activity based costing, Edisi Pertama. Yogyakarta: Expert 